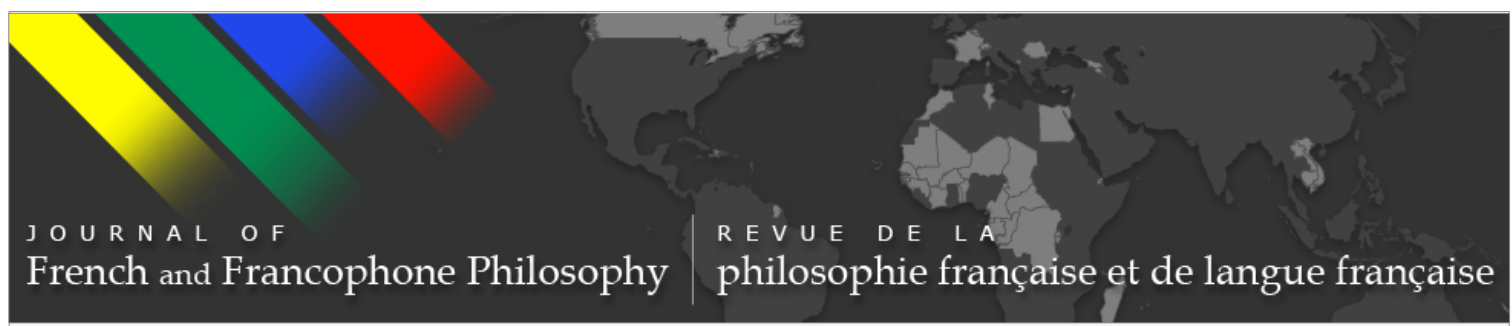

\title{
For A Time
}

\section{Kas Saghafi}

Journal of French and Francophone Philosophy - Revue de la philosophie française et de langue française, Vol XXIII, No 2 (2015) pp 122-130

\author{
Vol XXIII, No 2 (2015) \\ ISSN 1936-6280 (print) \\ ISSN 2155-1162 (online) \\ DOI 10.5195/jffp.2015.688 \\ www.jffp.org
}

\section{(oc) EY-NG-ND}

This work is licensed under a Creative Commons Attribution-Noncommercial-No Derivative Works 3.0 United States License.

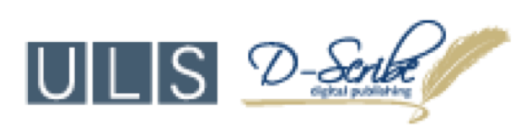

This journal is operated by the University Library System of the University of Pittsburgh as part of its D-Scribe Digital Publishing Program, and is co-sponsored by the University of Pittsburgh Press 


\section{For A Time}

\section{Kas Saghafi}

The University of Memphis

What is the time of "for a time?" How long is "for a time?" How long does survival last?

Less than an eternity, but not forever--for a time. ${ }^{1}$

In his brilliant book Miracle and Machine: Jacques Derrida and the Two Sources of Religion, Science, and the Media, Michael Naas patiently and thoughtfully analyzes what he dubs a great philosophical text on religion, namely, Derrida's essay "Faith and Knowledge" published in 1996. ${ }^{2}$ Naas's book, itself a major work on Derrida's thought, scrupulously guides and informs the reader about the structure and details of the "Faith and Knowledge" essay, which Naas calls "Derrida's most direct and ambitious attempt to answer the question of the nature of religion in general and its relationship with science and the media" (21). Unlike the so-called guides that have proliferated to meet the demands of academic presses, who themselves seem to have abandoned the thought of publishing probing intellectual research, Naas's Miracle and Machine is a genuine guide. Patiently explicated, expertly explained, demystifying without losing any sense of the complexity of Derrida's thought, Miracle and Machine discusses the structure, architectonics, and typography of "Faith and Knowledge," skillfully laying bare its why and wherefore, demonstrating how its form, style, and format reflect the theses within it.

With nine chapters, an Introduction, a Prologue, an Epilogue, an analysis of Don DeLillo's novel Underworld woven in as a sub-text, as a supplement, four substantial "Observations" on Kant, Hegel, Bergson, and Heidegger and a detailed and helpful timeline of Derrida's publications between 1993-1995 at the end of the book, Naas's Miracle and Machine masterfully brings together a macro- and micro-scopic reading, proceeding from the conditions and the context of the arguments of the book to the most minute details of its language and writing, in order to demonstrate the very complex stakes involved in the question of "religion." In addition to explicating an undoubtedly complex Derridean text--complex in its structure

Journal of French and Francophone Philosophy | Revue de la philosophie française et de langue française Vol XXIII, No 2 (2015) | www.jffp.org | DOI 10.5195/jffp.2015.688 
and its construction, its language and its thinking--following the logic of exemplarity, Naas's book also functions as a guide about the intricacies of a deconstructive reading, steering and gently instructing the reader as it carefully proceeds. In its sweep and detail, in the clichéd phrase that I find impossible to avoid here, it is not possible to do this work justice.

Naas shows "Faith and Knowledge" to be an "at once improvised and highly constructed" text full of repetitions, doublings and moments of duplicity. Demonstrating the duplicity inscribed into the very form of "Faith and Knowledge," in the two words of the title, naming the two sources of "religion," the two forms of religion, the dogmatic and the true, the division of the book into two sections (fifty-two sections composed of two sets of twenty-six), the two times and places of its writing: first, its presentation a small, informal gathering on the island of Capri, Italy in February 1994 and then, its writing at Laguna Beach, California in April 1995), the two, at least two, kinds of "writing," the spoken and the written, the two forms of typescript or font, the further division of the text into the bolded and the unbolded, Naas also shows that Derrida's arguments do not proceed in a logical and linear fashion but are scattered throughout, progressing nonetheless by a constant doubling back to its themes and motif.

Even though Derrida's arguments are not made in a straightforward fashion, it is Naas's contention that we can isolate three main theses underlying "Faith and Knowledge." Naas isolates them in a chapter (that he must have had great fun titling) called "Three Theses on the Two Sources and Their One Common Element." According to Naas, these express: the fundamental duplicity of religion, the fundamental conflict between science and religion, and the fundamental complicity of religion and science (65). While I am not able to pursue the full details of these topics here, I can highlight the focus on elementary trust, reliability or, trustworthiness [fiabilité].

Among the discussions that I found extremely illuminating and that I greatly learned from in Miracle and Machine are: the treatment of the question of salut, salut as salvation or as safety (50-2) and mondialisation, the process of becoming world-wide (58) in Chapter 2; the discussion of the miracle as being coextensive with elementary faith (93-4) and testimonial faith's conditioning of every social bond as an interruption, as an interruptive unraveling $(94-5,97-9)$ in Chapter 3; the theme of breath (souffle) (110-4), the connection between the machine (118) and faith, showing that it is the machine that makes possible the faith that opens up a future (120) in Chapter 4; the experience of the secret (127), in particular its relation to Christianity as a religion of internalization, of the virtualization and spectralization of the body of Christ in the Eucharist, explaining the divergent uptakes by the Abrahamic religions of what took place and was said between YHWH and Abraham, as well as the specificity of Islam's attachment to the untranslatable letter and its resistance to mediatization

Journal of French and Francophone Philosophy | Revue de la philosophie française et de langue française Vol XXIII, No 2 (2015) | http://www.jffp.org | DOI 10.5195/jffp.2015.688 
and translation (131) in Chapter 5; the penetrating examination of the most desert-like khorra and the rethinking of "religion" itself on the basis of another social bond, the one that first opens up, and interrupts in opening up, every community (195) in Chapter 6; the consideration of "the ellipsis of sacrifice" (207) and the discussion of how when the specter of life-death is repressed the phantasm of pure life takes its place (225) in Chapter 7--and I haven't even mentioned yet the grenade and the pomegranate seeds in Chapter 8.

Rather than engaging in a mechanical exercise of summary here, I would like to submit to scrutiny--the very scrutiny that he himself practiced when I had the privilege of being in his classes, in which he examined minute details of Platonic arguments--Naas's discussion of an important theme raised at the end of his book, that of survival or living on [survivre]. I would like to take the opportunity here to think through with Naas a most pressing thought invoked in Chapter 9, entitled "The Passion of Literature: Genet in Laguna, Gide in Algiers." There, Naas takes up the unusual juxtaposition of two writers who were important for Derrida during different phases of his life: Gide especially during his youth, and Genet, who played an important role in Derrida's work, certainly since the composition of Glas. Toward the end of Chapter 9, after speculating about the role played by these writers in "Faith and Knowledge" and presenting a hypothesis about their presence at the end of the essay, Naas turns to Derrida's views regarding death and the acceptance of death.

Examining the notion of "the end" in the Western tradition that Derrida is reading, Naas remarks that in this tradition the end is never quite the end. For there is always something that comes after the end, "something like an afterlife or an afterworld, some kind of life ever-lasting" (263-4). What about Gide of Fruits of the Earth, the Journals or even The Immoralist may have appealed to Derrida, Naas writes, is his "unconditional embracing of life in the here and now, on earth and in this world, rather than sacrificing this world and this life to some beyond" (264). Bringing together his discussion of Gide with Derrida's "final words," words scribbled on an envelope, as he says, near the end of his life and read aloud by his son, Pierre Alferi, at his gravesite in Ris-Orangis, Naas concludes that in their "emphasis on this world, this finite world" both Derrida and Gide issue a plea not to sacrifice this world for the promise of another world.

Naas explains that Gide's reference to the very common expression de l'autre côté, on the other side, very much like Nietzsche's thought, eschews an otherworldly religion or ethics, for what is promised on the other side of life, and encourages the celebration of the joys and riches of this world. One may wonder how to distinguish a thought embracing the wonders of this life from other competing discourses on finitude such as Nietzschean tragic finitude, or a certain embrace of Carpe diem by the existentialists, for whom Gide was a favorite author. Of course, such a belief, as Naas rightly worries,

Journal of French and Francophone Philosophy | Revue de la philosophie française et de langue française

Vol XXIII, No 2 (2015) | http://www.jffp.org | DOI 10.5195/jffp.2015.688 
can lead to the neglect of "the 'other side' that is to be found on this side, that is of the other world within this world" (267). He will go on to explain what he means by this other side within this world.

Having already referred to the appeal that Derrida makes to the phrase de l'autre côté in Chapter 3, Naas writes that for Derrida there is already "another side to this 'other side,' not some other world beyond this world but an 'other side' or an 'other world' within this world" (267). This "other side" is "not some other world to which I might gain entrance after death but [rather] the inner sanctum of the other, to which I can have no access" (267). For this reason, Naas writes, there is "another other world, but not one above or beyond this one but another world 'within' the world, an infinitely other, nondialectizable, nonsynthesizable world 'within' this one" (268). And this thought becomes most poignant with the death of the other.

At this juncture in his chapter, Naas admits that it would be difficult not to want to pose the question, the question that many readers of Derrida may have been wondering about, about whether Derrida himself believed in another world or in an afterlife. Quoting Derrida's own statements about his own death, for example the one in A Taste for the Secret when he said "I do not believe that one lives on post mortem," Naas says declaratively that "Derrida did not believe that we live on somewhere else or that we live again; he did not believe in another world; in a world 'on the other side' of this one" (270). Glossing this further, Naas observes that "while we are not resurrected for another life or in another life, 'we' do sur-vive or live on for a time after death through the traces we produce and the marks that make us visible to others. [...] 'We' begin sur-viving or living on from the moment we are born" (270; my emphasis). This surviving is, as Derrida wrote in Archive Fever, "the surviving of an excess of life" over itself. ${ }^{3}$

In what follows I would like to underscore Naas's use of the phrase "for a time" toward the end of Chapter 9 in four other instances (one of them italicized by him). Now I claim no expertise in numerology, and in the wake of Naas's own book that makes a great case for the significance of all kinds of numbers in Derrida's "Faith and Knowledge," I cannot say anything substantial about this number of repetitions--five--except to point out his emphasis on the expression "for a time." My remarks or questions will have to do with how to understand this "for a time."

Commenting on Derrida's views about death and what may come after it, Naas goes on to say that Derrida's work argued for and demonstrated a logic of survival and living on from the very beginning, though this should not be mistaken for a belief in an afterlife. "Derrida developed throughout his work," Naas writes, "a singular thinking of survival or living on, a notion of the trace as what, in principle if not in fact, always survives the one who produced it or received it [...] As soon as I utter or even read a trace, as soon as I make a mark, my death and my survival are implied therein, my

Journal of French and Francophone Philosophy | Revue de la philosophie française et de langue française Vol XXIII, No 2 (2015) | http://www.jffp.org | DOI 10.5195/jffp.2015.688 
death and the trace or mark that can always survive me for a time" (Here I note the second appearance of the phrase "for a time") (271; my emphasis). In other words, the trace survives me: "while every trace--as finite--is threatened by forgetting, erasure, indeed by catastrophe or apocalypse, the trace in principle survives me" (271). However, this powerful thought of survival is "a far cry from any kind of belief in an afterlife or in the immortality of the soul" (271).

We begin living on already from the beginning, and we continue to live on in these very marks, these signs, after our deaths. But how then to understand this living on? When Derrida says in his final note "I love you and am smiling at you from wherever I am," Naas emphasizes that "We are to understand living on as living on only "in' these words," in the subjunctive and not in the indicative, "as they are repeated or as they remain repeatable in others, for others-and only for a time" (271, author's italics, the third appearance of the phrase). So, only in the time of "for a time." Derrida did not believe, Naas continues, in an afterlife or in an eternal or immortal life after death but "always only a finite and very mortal survival" (272). Here we could ask what a "finite" and "mortal" survival would be? If Derrida has been rethinking "finitude" from his earliest texts, combining a thinking of finitude with that of the infinite, surely we cannot take "finite" and "mortal" here as simply the end of a short, death-bound life on this earth, especially since in several other places, such as The Beast and the Sovereign, volume 2, Derrida links finitude with a survivance that is "neither life nor death pure and simple." There, writing of the alliance of the living and the dead, he states "this finitude [...] is survivance." ${ }^{4}$ Perhaps survivance requires that we think the finite in relation to the infinite. In other words, would we be able to think of living on as infinitely finite?

Naas very astutely notes that "it might be thought that this living on is something of a consolation in the face of death, solace in the recognition that, although we are not immortal, the traces we leave live on within the world in the memories of others, in the works available to others to read, hear, or experience, and so on" (272). Yet, Naas explains that Derrida's survival is, first, anything but a "personal" survival, "for the trace I leave behind is precisely not "my own'" and second, that "with every death, including my own, there comes the end not of some individual within the world but the end of the world as such" (272). This end of the world is, of course, a reference to a notion that Derrida argued for in the Preface to the French edition of The Work of Mourning, entitled Chaque fois unique, la fin du monde, where he emphatically stated that the death of the other signifies not the end of $a$ world but the end of the world itself. As Naas notes, Derrida rejects the thought that my death can be understood and situated dialectically within the horizon of other deaths. In other words, Derrida does not agree with the idea of a common horizon of death. For, death truly is "the end of the world."

Journal of French and Francophone Philosophy | Revue de la philosophie française et de langue française

Vol XXIII, No 2 (2015) | http://www.jffp.org | DOI 10.5195/jffp.2015.688 
Since Derrida did not believe that he would be going to another world, Naas writes, "there might be living on for a time, but certainly no afterlife" (272, my emphasis, fourth appearance). For, despite his genuine struggle and constant preoccupation with death, Derrida could not accept death. "He could not accept death because he--like all of us--had a certain preference for life" (273). He could not accept it because he could not think or assimilate it; he could not accept it because he wished to question and thus rethink the concepts he had inherited from the tradition, in particular, those of redemption and resurrection. We can say that what he thought was always on the side of life, as he described the thought of Hélène Cixous in H.C., That is To Say...

Derrida "simply could not accept death," Naas argues, "because to do so would be to accept nothing less than the end of the world" (273). Thus, the acceptance of [his own] death would be tantamount to accepting the end of the world. It is true that Derrida could not accept death in the sense of resigning himself to it. This he could never do, but he did accept death as the end of the world; he did know that death would be the end of the world. I would like to say a few more words about this at the end of my paper.

Naas then writes that for Derrida there is living on but there would be no resurrection (274). With every breath one is already living on, surviving, not at all immortal but living on as absolutely mortal. As Naas shows throughout the book, Derrida's thinking of the trace was always tied to a reflection on death and mourning, a mourning that begins from the very beginning. "Only insofar as work allows itself to be [...] uprooted, displaced, and translated, transplanted elsewhere, can it live on for a time" (274, my emphasis, fifth appearance). How do we take this emphasis again on "absolutely mortal?" Surely, this mortality is not that of a dying subjectivity or of a simple finitude. How would we reconcile the relation between mortality and a certain living on, surviving, remaining [restance], ghostly coming back [revenance], that is, a certain immortality? When in one of the first substantial treatments of the notion of survival in an essay on Blanchot called "Living On: Borderlines", Derrida remarks that in L'Arrêt de mort the living on [survivance] of the one who narrates [le récitant], who is a survivor, is also a spectral coming back, a ghostly return [cette survivance est aussi une revenance spectrale], what is the time or duration of this survival? ${ }^{5}$ Is its time only "for a time?"

Perhaps with his stress on the expression "for a time" Naas is emphasizing the provisional nature of survival and living on, survival for a time, in the same way that he argues in Chapter 6 "'Jewgreek is Greekjew': Messianicity-Khôra-Democracy," that Derrida was not willing to give up the notion of the messianic "for the moment" (172). Or perhaps Naas wants to say that survival lasts "for a time," as in the duration of one's epoch. One way of reading the thought that one lives on "for a time" after one's death, would be to say that the memory that others have of oneself lasts only for a

Journal of French and Francophone Philosophy | Revue de la philosophie française et de langue française Vol XXIII, No 2 (2015) | http://www.jffp.org | DOI 10.5195/jffp.2015.688 
time, only for one's time, for one's epoch, after which this memory naturally dissipates. In a wonderfully strange text entitled “'Dead Man Running': Salut, Salut," written in honor of the $50^{\text {th }}$ anniversary of Les Temps modernes, Derrida comments on this very thought, on what you might perhaps call Sartre's over-zealous belief in finitude. In this hastily-written essay penned in the form of a letter to Claude Lanzmann, Derrida links epochalization, the fact that one's thought belongs to an epoch, to the process of sanctification, showing an alliance between the concept of epoch and the concept of salvation. For Derrida, this emphasis on epochalization is predetermined and overdetermined by the value of life. So does memory just endure "for a time," the time of one's epoch?

Or perhaps, like the Homeric belief in the fame or reputation that outlasts the hero's lifetime, survival is akin to the living on of memory. This would, then, be something like a living on in posterity, the survival that posterity promises. For Homeric kleos, honor and glory is bestowed upon the hero who has died a glorious death and whose memory will live on. The hero's desire is to perform great deeds in order to transform his death into eternal glory. In the Iliad Hektor does not intend to die without "some great deed whose fame will live on among men to come [essomenoisi puthesthai]." ${ }^{6}$ The beautiful death (kalos thanatos), the glorious death (eukleess thanatos), in the prime of youth leads to glory, virtually guaranteeing unassailable renown. The logic underlying heroic honor is the need to be recognized as supreme, to be famed "among men to come [hommes à venir]." ${ }^{7}$

Heroic striving has its roots in the will to escape aging and death, which amount to amnesia, silence, demeaning obscurity, and the absence of fame. By welcoming death and confronting it with valor, death is overcome as something to be feared. What matters most is being valued, honored, and recognized and by being glorified in a song of praise the hero is allowed to continue, beyond the reach of death, to be present in the community of the living, his life converted into legend and linked to that of other heroic individuals. In his analysis of "glorious death," Jean-Pierre Vernant notes that this kleos, of course, assumes the existence of a tradition of oral poetry which serves as a repository of shared culture and as societal memory. The hero who is praised in song is not only committed to memory, memorialized, remaining present in the memory for all "those to come" but also commemorated in the memorial tomb, the raising of a sema.

When Naas writes that accepting death is something Derrida could never do because it would be equivalent to accepting the end of the world, he appeals to Derrida's words in Learning to Live Finally: "We are all survivors who have been granted a temporary reprieve [en sursis]" in order to underscore the temporariness of this "for a time." ${ }^{8}$ However, isn't the reprieve that Derrida is referring to here that of the duration of our life--the duration of our life itself as a reprieve--and not what happens after it? It is

Journal of French and Francophone Philosophy | Revue de la philosophie française et de langue française Vol XXIII, No 2 (2015) | http://www.jffp.org | DOI 10.5195/jffp.2015.688 
our life itself, the life that is riven with death and will live on, that Derrida considers as a temporary reprieve (273).

Furthermore, almost every time that Derrida wrote about the end of the world, whether it was in The Work of Mourning or in Rams, was it not always in relation to the other's death, and not in reference to his own or the death of "the I?" When Naas writes that in the Preface of Chaque fois unique Derrida made it very clear that "death--in this case, the death of the other--must be understood not as an event within the world [...] but as the end of the world itself," does he mean to suggest that Derida could also have been referring to "death in general" or "my death?" Is Naas implying that this case, this particular case, that of the other's death, is just an example to be included among the rest? (273, my emphasis). Or was it a mere coincidence that whenever Derrida wrote about "the end of the world" it was the death of the other that provoked his discussion? Can we say that it is not just "in this case," but only in this case, the case of the other's death, that he speaks of it?

Every death of the other, each time, is the end of the world. This is because the other's death is the end of the world envisioned as something that we commonly share. The death of the other is a reminder that what we call "the world," the fact that we believe that there is only one world is the result of a tacit agreement, a shared history. For "the world"-whether the kosmos, the universe, or the globe-does indeed have a history, a history that requires to be told again. With the other's death so dies a certain concept of the world as one world. Each birth opens up and each death closes a "unique world." 9 The other's is "an other world." And each death, each time, signals "another end of the world." ${ }^{10}$ With each death there is a world that disappears. It will be claimed that, nevertheless, the "world" is there. Derrida believed that what we call "the world" is the indispensable assumption or presumption of a "credible" gathering, the gathering of an infinity of worlds, depending on an act of faith. The presumption of a community, a gathering of this infinite dispersion of worlds, is faith itself.

With the invocation of faith, it is time once again to say what a miraculous work Naas's book is, miraculous in the sense that he helps us understand that a marvelous event causes wonder. In Miracle and Machine he shows us that this miracle could not be understood without a relationship to calculation, programming, and repetition. And the wonder is that to accede to the event of this miracle we had to pass via the machine, via all the repetitions and duplicities recounted and marvelously mapped out through the chapters of Miracle and Machine. 
1 This paper was originally presented at a SPEP Session on Michael Naas's Miracle and Machine in Eugene, Oregon October 24, 2013. Paul Davies was my co-panelist.

2 Michael Naas, Miracle and Machine: Jacques Derrida and the Two Sources of Religion, Science, and the Media (New York: Fordham University Press, 2012). Further references shall be given in the body of the text.

3 Jacques Derrida, Mal d'Archive. Une impression freudienne (Paris: Galilée, 1995), 96 ; Archive Fever, trans. Eric Prenowitz (Chicago: University of Chicago Press, 1996), 60.

4 Jacques Derrida, Séminaire La bête et le souverain. Volume II (2002-2003), ed. Michel Lisse, Marie-Louise Mallet, and Ginette Michaud (Paris: Galilée, 2010), 193; The Beast \& the Sovereign, Volume II, trans. Geoffrey Bennington (Chicago: University of Chicago Press, 2011), 130.

5 Jacques Derrida, Parages (Paris: Galilée, 1986), 182; Parages, ed. John P. Leavey, trans. Tom Conley, James Hulbert, John P. Leavey, and Avital Ronell (Stanford: Stanford University Press, 2011), 159.

${ }^{6}$ Homer, lliad (22.304-5).

7 Jean-Pierre Vernant, "La belle mort et le cadavre outragé," in L'individu, la mort, l'amour: Soi-même et l'autre en Grèce ancienne (Paris: Gallimard, 1989), 50; “A 'Beautiful Death' and the Disfigured Corpse in Homeric Epic," in Mortals and Immortals: Collected Essays, ed. Froma I. Zeitlin (Princeton, NJ: Princeton University Press, 1991), 55.

8 Jacques Derrida, Apprendre à vivre enfin: Entretien avec Jean Birnbaum (Paris: Editions Galilée/Le Monde, 2005), 25; Learning to Live Finally: The Last Interview, trans. Pascale-Anne Brault and Michael Naas (Hoboken, NJ: Melville House Publishing, 2007), 24.

9 Jacques Derrida, Echographies--de la télévision (Entretiens filmés avec Bernard Stiegler) (Paris: Galilée, 1996), 138; Echographies of Television: Filmed Interviews, trans. Jennifer Bajorek (Malden, MA: Blackwell, 2002), 123.

10 Jacques Derrida, Chaque fois unique, la fin du monde (Paris: Galilée, 2003), 124; The Work of Mourning, ed. Pascale-Anne Brault and Michael Naas (Chicago: University of Chicago Press, 2001), 95.

Journal of French and Francophone Philosophy | Revue de la philosophie française et de langue française Vol XXIII, No 2 (2015) | http://www.jffp.org | DOI 10.5195/jffp.2015.688 